\title{
PROFIL PROTEIN IKAN GABUS (Channa striata), TOMAN (Channa micropeltes), DAN BETUTU (Oxyeleotris marmorata)
}

\author{
Mala Nurilmala ${ }^{1 \star}$, Mega Safithri $^{2}$, Fitria Tika Pradita ${ }^{1}$, Rizsa Mustika Pertiwi ${ }^{1}$ \\ ${ }^{1}$ Departemen Teknologi Hasil Perairan, FPIK IPB University, Jalan Agatis, Kampus IPB Dramaga, \\ Kabupaten Bogor 16680 Jawa Barat Telepon (0251) 8622915, faks (0251) 8622916 \\ ${ }^{2}$ Departemen Biokimia, FMIPA IPB University, Jalan Meranti Dramaga, Kabupaten Bogor 16680 Jawa \\ Barat Telepon (0251) 8423267 \\ Diterima: 28 Agustus 2020/Disetujui: 28 Desember 2020 \\ *Korespondensi: mnurilmala@apps.ipb.ac.id
}

Cara sitasi: Nurilmala M, Safithri M, Pradita FT, Pertiwi RM. Profil protein ikan gabus (Channa striata), toman (Channa micropeltes), dan betutu (Oxyeleotris marmorata). Jurnal Pengolahan Hasil Perikanan Indonesia. 23(3): 548-557.

\begin{abstract}
Abstrak
Channa striata atau yang dikenal dengan ikan gabus adalah ikan air tawar yang memiliki banyak manfaat untuk kesehatan, khususnya kandungan albuminnya untuk penyembuhan luka. Jenis ikan air tawar lain yang diduga memiliki potensi albumin selain ikan gabus adalah ikan toman (Channa micropeltes) dan ikan betutu (Oxyeleotris marmorata). Penelitian ini bertujuan menentukan profil protein albumin pada ikan gabus, toman, dan betutu. Metode yang dilakukan yaitu ekstraksi protein, pengukuran kadar protein serta identifikasi profil protein dengan SDS-PAGE. Pengukuran kadar protein dilakukan pada ekstrak ikan segar, rebus, dan setelah pemurnian dengan presipitasi amonium sulfat. Kadar protein pada ekstrak ikan gabus segar $11,62 \pm 0,17 \mathrm{mg} / \mathrm{g}$, rebus $6,28 \pm 0,57 \mathrm{mg} / \mathrm{g}$ dan murni 105,23 $\pm 0,44 \mathrm{mg} / \mathrm{g}$. Kadar protein ekstrak ikan toman segar $10,47 \pm 0,17 \mathrm{mg} / \mathrm{g}$, rebus $8,19 \pm 0,33 \mathrm{mg} / \mathrm{g}$ dan murni 42,76 $\pm 1,65 \mathrm{mg} / \mathrm{g}$. Kadar protein ekstrak

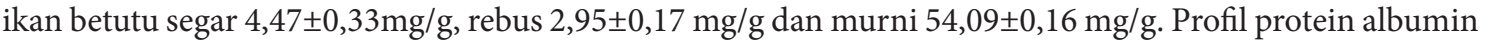
pada ikan gabus, toman dan betutu memiliki bobot molekul 50-52 kDa.
\end{abstract}

Kata kunci: albumin, Channa striata, Channa micropeltes, Oxyeleotris marmorata, SDS-PAGE

\section{Protein Profile of Striped Snakehead (Channa striata), Giant Snakehead (Channa micropeltes), and Marble Goby (Oxyeleotris marmorata)}

\begin{abstract}
Channa striata has benefit for human health, especially albumin content as wound healing. The other fish species that have potential source of albumin are toman fish (Channa micropeltes) and betutu fish (Oxyeleotris marmorata). This study aims to determine the protein albumine profile in snakehead, toman, and betutu fish. The method included protein extraction, measurement of protein content and identification of protein profiles using SDS-PAGE. The protein contents in fresh, boiled, and pure of gabus fish were $11.62 \pm 0.17 \mathrm{mg} / \mathrm{g}, 6.28 \pm 0.57 \mathrm{mg} / \mathrm{g}$, and $105.23 \pm 0.44 \mathrm{mg} / \mathrm{g}$ respectively, while fresh, boiled, and pure of toman fish were $10.47 \pm 0.17 \mathrm{mg} / \mathrm{g}, 8.19 \pm 0.33 \mathrm{mg} / \mathrm{g}$, and $42.76 \pm 1.65 \mathrm{mg} / \mathrm{g}$ respectively. In addition, the protein content of fresh, boiled, and pure of betutu fish were $4.47 \pm 0.33 \mathrm{mg} / \mathrm{g}, 2.95 \pm 0.17 \mathrm{mg} / \mathrm{g}, 54.09 \pm 0.16$ $\mathrm{mg} / \mathrm{g}$, respectively. The albumin profile in snakehead, toman and betutu fish has predicted with a molecular weight of $50-52 \mathrm{kDa}$.
\end{abstract}

Keyword: albumin, Channa striata, Channa micropeltes, Oxyeleotris marmorata, SDS-PAGE 


\section{PENDAHULUAN}

Protein merupakan suatu zat makanan yang penting bagi tubuh karena protein memiliki fungsi sebagai zat pembangun dan zat pengatur. Protein sebagai zat pembangun memiliki fungsi sebagai bahan pembentuk jaringan-jaringan baru yang selalu terjadi dalam tubuh. Protein sebagai zat pengatur berfungsi untuk mengatur keseimbangan cairan dalam jaringan dan pembuluh darah, yaitu dengan menimbulkan tekanan osmotik koloid yang dapat menarik cairan dari jaringan ke pembuluh darah. Protein juga merupakan sumber asam amino yang mengandung unsur $\mathrm{C}, \mathrm{H}, \mathrm{O}$, dan $\mathrm{N}$ yang tidak dimiliki oleh karbohidrat dan lemak.

Kandungan protein dalam bahan pangan bervariasi, baik dalam jumlah maupun jenisnya. Ikan merupakan salah satu bahan pangan hewani yang mengandung protein tinggi. Kandungan protein pada ikan lebih tinggi jika dibandingkan dengan bahan pangan lainnya, misalnya telur dan daging (Kusnandar 2010).

Jenis protein yang terdapat pada ikan adalah protein sarkoplasma, miofibril, dan stroma. Albumin merupakan salah satu jenis protein sarkoplasma yang saat ini banyak diteliti dan dikembangkan karena memiliki banyak fungsi untuk kesehatan. Albumin memiliki fungsi sebagai pembentukan jaringan sel baru, mempercepat pemulihan jaringan sel yang rusak, serta memelihara keseimbangan cairan di dalam rongga pembuluh darah dengan cairan di rongga interstitial (Andreeva 2010). Jenis perikanan air tawar yang sudah banyak diteliti mengenai kandungan proteinnya, khususnya albumin adalah ikan gabus. Albumin dari ikan gabus saat ini banyak digunakan untuk obat penyembuhan luka (Baie 2000).

Ikan gabus merupakan jenis ikan air tawar yang memiliki albumin tinggi. Ikan ini banyak dimanfaatkan di bidang kesehatan dan farmasi (Jamaluddin et al. 2011). Nugroho (2012) melaporkan bahwa kandungan albumin pada ikan gabus sebesar 2,459 g/100 g. Asikin dan Kusumaningrum (2018) melaporkan bahwa kadar albumin pada ikan gabus $<600$ g yaitu $15,26 \%$; $<900$ g yaitu $17,85 \%$ dan $<1200$ g yaitu $14,23 \%$.
Ikan gabus dari sudut pandang kesehatan juga mengandung protein (khususnya albumin) yang diperlukan bagi proses penyembuhan dan pertahanan tubuh, selain itu ikan gabus juga memiliki kandungan karbohidrat dan lemak yang rendah. Jenis ikan air tawar lainnya yang diduga memiliki albumin dan protein tinggi adalah ikan toman (Channa micropeltes) dan ikan betutu (Oxyeleotris marmorata). Alvodinasyari et al. (2019) melaporkan bahwa kadar protein ikan gabus dan ikan toman tidak berbeda. Kadar protein yang terkandung dalam ikan gabus dan toman yaitu $0,803 \mathrm{mg} / \mathrm{mL}$. Fitriyani et al. (2020) melaporkan bahwa ikan ikan toman dari perairan Kalimantan Barat mengandung kadar albumin 3,6147 gr/dL yang sedikit lebih tinggi dibandingkan dengan kadar albumin dari ikan gabus 3,3076 gr/dL.

Ekstraksi albumin pada suhu $70{ }^{\circ} \mathrm{C}$ selama 25 menit merupakan salah satu ekstrasi terbaik untuk mendapatkan albumin dari ikan toman. Protein yang terkandung $53,17 \%$; lemak $8,45 \%$; air $8,04 \%$; abu $8,36 \%$; karbohidrat $21,98 \%$ serta $\mathrm{Zn} \quad 0,33 \mathrm{mg} / \mathrm{L}$ (Fitriyani dan Deviarni 2018). Ekstrak ikan toman salah satunya diaplikasikan dalam produk hidroksipropil metilselulosa (HPMC) yang dapat dijadikan sediaan gel untuk produk kosmetika dan makanan. Penambahan ekstrak ikan toman pada konsentrasi 0-4,5\% memberikan homogenitas yang baik untuk pembuatan gel HPMC (Firlianty et al. 2019).

Ikan betutu juga dilaporkan memiliki protein yang tinggi. Ikan betutu dari Sumatra Selatan mengandung kadar protein total 5,95 $\mathrm{mg} / \mathrm{g}$, protein larut air $1,83 \mathrm{mg} / \mathrm{g}$ dan protein larut garam 3,50 mg/g (Gultom et al. 2015). Protein yang tergolong larut air salah satunya yaitu albumin. Protein albumin banyak di aplikasikan pada berbagai produk pangan salah satunya dalam formula bubur bayi instan agar dihasilkan MP-ASI yang dapat memenuhi kebutuhan zat gizi (Sari et al. 2017). Penelitian lebih lanjut terhadap ikan gabus, toman dan betutu diperlukan untuk mengetahui karakteristik bahan baku dan profil proteinnya karena informasi mengenai hal tersebut masih sedikit. Identifikasi profil protein dilakukan pada masing-masing ikan dengan perlakuan segar, rebus, dan 
pemurnian. Perlakuan tersebut dilakukan untuk membandingkan jenis ikan yang memiliki kadar protein tertinggi setelah diberikan perlakuan. Identifikasi profil protein juga dilakukan dengan elektroforegram SDSPAGE untuk mengidentifikasi keberadaan protein albumin pada ketiga ikan tersebut. Penelitian ini bertujuan menentukan profil protein albumin pada ikan gabus, toman, dan betutu pada ekstrak segar, ekstrak setelah perebusan dan setelah pemurnian.

\section{BAHAN DAN METODE Bahan dan Alat}

Bahan yang digunakan dalam penelitian ini adalah ikan gabus, ikan toman, dan ikan betutu dari Ciawi, Bogor, Jawa Barat, serta ekstrak komersial ikan gabus dari Semarang, Jawa Tengah. Bahan lainnya meliputi air deionisasi, $\mathrm{NaHPO}_{4} \cdot 2 \mathrm{H}_{2} \mathrm{O}$ (Merck, Jerman), $\mathrm{NaH}_{2} \mathrm{PO}_{4} \cdot 4 \mathrm{H}_{2} \mathrm{O}$ (Merck, Jerman), tris base (Merck, Jerman), $\mathrm{CH}_{3} \mathrm{COOH}$ (Merck, Jerman), $\mathrm{NaCH}_{3} \mathrm{COO}$ (Merck, Jerman), amonium sulfat (teknis), asam fosfat 85\% (Merck, Jerman), Bovine Serum Albumine (Sigma, AS), SDS (Merck, Jerman), glisin (Merck, Jerman), gliserol (Merck, Jerman), amonium persulfat (Sigma, AS), $\beta$-merkaptoetanol (Merck, Jerman), Coomasie Brilliant Blue (Merck, Jerman), metanol (Merck, Jerman), asam asetat glasial (Merck, Jeman), bromphenol blue (Merck, Jerman), dan marker protein (Prestained Protein Markers Broad Range for SDSPAGE code 02525-35, Nacalai, Jepang).

Alat-alat yang digunakan dalam penelitian ini meliputi timbangan digital (PGW 254, ADAM, Inggris), waterbath (SB30T WIGGEN Hauser, Jerman), sentrifuse (J221 BECKMAN, Jerman), spektrofotometer (Spectro UV-VIS 2500, Jerman), pipet tips 1-200 $\mu \mathrm{L}$ (Axygen Scientific, California, AS), $\mathrm{pH}$ meter (Thermo Electron, Finlandia), micropipette 2-20 $\mu \mathrm{L}, 20-200 \mu \mathrm{L}$, dan $1000 \mu \mathrm{L}$ (Thermo Scientific Vantaa, Finlandia), serta alat elektroforesis (TV100YK, SCIE-PLAS, Inggris).

\section{Metode Penelitian \\ Preparasi ikan gabus, toman, dan betutu}

Ikan gabus, toman, dan betutu segar ditimbang bobot utuhnya kemudian dilakukan proses preparasi. Proses preparasi meliputi penyiangan, pencucian, dan penimbangan proporsi bagian tubuh masing-masing ikan. Daging ikan yang digunakan telah bersih dari kulit dan bagian tubuh lainnya kemudian disimpan dalam freezer pada suhu $-20^{\circ} \mathrm{C}$ untuk analisis selanjutnya.

\section{Ekstraksi daging ikan gabus, toman, dan betutu}

Ekstraksi daging ikan mengacu pada Fatoni (2007) dan Muhammad et al. (2014) yang dimodifikasi. Daging dari masingmasing sampel diambil sebanyak $400 \mathrm{~g}$, dipotong kecil-kecil dicampur dengan dengan pelarut akuades (perbandingan 1:2) dan dihomogenkan menggunakan homogenizer. Ekstrak daging sebanyak $100 \mathrm{~mL}$ disaring menggunakan kain belacu sebagai sampel segar. Ekstrak sisanya direbus dalam waterbath suhu 60 C selama 25 menit, kemudian disaring dengan kain belacu. Filtrat segar dan hasil perebusan masing-masing disentrifugasi dengan kecepatan $5.000 \mathrm{~g}$ selama 20 menit pada suhu $4{ }^{\circ} \mathrm{C}$. Filtrat (ekstrak kasar) selanjutnya dimasukkan dalam botol dan disimpan dalam freezer pada suhu $-20{ }^{\circ} \mathrm{C}$ untuk analisis selanjutnya.

\section{Pemurnian ekstrak dengan presipitasi menggunakan amonium sulfat}

Proses presipitasi merupakan langkah untuk mendapatkan protein murni menggunakan amonium sulfat mengacu pada (Fatoni 2007). Amonium sulfat ditambahkan ke dalam ekstrak kasar sampel setelah perebusan dengan variasi tingkat kejenuhan $70 \%$ hingga $90 \%$. Penambahan amonium sulfat dilakukan sedikit demi sedikit di atas stirrer dengan kecepatan sedang agar tidak terbentuk buih. Suhu yang digunakan selama proses presipitasi adalah $4{ }^{\circ} \mathrm{C}$. Larutan yang telah jenuh setelah ditambahkan amonium sulfat selanjutnya didiamkan selama satu malam pada suhu chilling. Larutan yang telah didiamkan selama satu malam selanjutnya disentrifugasi dengan kecepatan $5.000 \mathrm{~g}$ pada suhu $4{ }^{\circ} \mathrm{C}$ selama 20 menit. Pelet yang diperoleh kemudian dilarutkan dengan bufer fosfat $0,1 \mathrm{M} \mathrm{pH} 5$ dan diukur kadar 
proteinnya. Hasil pengendapan amonium sulfat terbaik ditentukan berdasarkan kadar protein tertinggi.

\section{Identifikasi profil protein dengan elektroforegram SDS-PAGE}

Profil protein dilakukan menggunakan metode Sodium Deodesyl SulfatePolyacrilamide Gel Electrophoresis (SDSPAGE) mengacu pada (Laemmli 1970) menggunakan stacking gel 3\% dan separating gel 12,5\%. Pembuatan separating gel dilakukan selama kurang lebih 30 menit, sedangkan pembuatan stacking gel dilakukan selama kurang lebih 2 jam. Pemasukan sisir/comb dilakukan saat proses pembuatan stacking gel untuk membentuk sumur-sumur pada gel.

Ekstrak ikan gabus komersial, ekstrak segar, rebus, dan hasil presipitasi ammonium sulfat dari masing-masing sampel dengan variasi pengendapan $70 \%, 80 \%$, dan $90 \%$, serta supernatan dari masing-masing pengendapan amonium sulfat selanjutnya dilarutkan dengan bufer sampel 1:1 (v/v). Sampel yang telah dicampurkan dengan bufer sampel selanjutnya didenaturasi dengan cara dipanaskan dalam waterbath pada suhu $95^{\circ} \mathrm{C}$ selama kurang lebih 3 menit. Bufer running selanjutnya ditambahkan ke dalam alat elektroforesis hingga tanda batas.

Marker protein dan sampel yang telah didenaturasi masing-masing diambil sebanyak $5 \mu \mathrm{L}$ dan dimasukkan ke dalam sumur gel poliakrilamid. Marker protein yang digunakan yaitu 8,8-192 kDa. Proses elektroforesis dilakukan pada arus $13 \mathrm{~mA}$ dan voltase 150 $\mathrm{V}$ dengan Mini Protein (SCIE PLAST) selama kurang lebih 3 jam. Pewarnaan gel (staining) dilakukan menggunakan 0,125\% Coomasie brilliant blue selama 2 jam hingga gel berwarna biru. Proses pencucian (destaining) dilakukan menggunakan 25\% metanol dan $10 \%$ asam asetat selama satu malam hingga warna gel menjadi bening dan pita protein sudah terlihat. Proses pewarnaan dan pencucian gel dilakukan diatas alat shaker. Perhitungan berat molekul dilakukan dengan perangkat lunak Photocapt. Pengukuran luasan area pita protein dilakukan dengan perangkat lunak Image-J.

\section{Analisis Data}

Analisis data ekstrak protein dilakukan secara statistik. Rancangan percobaan yang digunakan yaitu rancangan acak lengkap (RAL). Analisis data berat molekul (BM) menggunakan perangkat lunak Photocapt, kemudian dilakukan perhitungan luasan area dengan perangkat lunak Image-J dan disajikan secara deskriptif.

\section{HASIL DAN PEMBAHASAN \\ Karakteristik Ikan Gabus, Toman, dan Betutu}

Pengukuran morfometrik dilakukan terhadap ikan gabus, ikan toman, dan ikan betutu menggunakan tiga ekor ikan pada setiap spesies. Parameter yang diamati yaitu panjang, lebar, dan bobot total. Morfometrik ikan gabus, toman, dan betutu dapat dilihat pada Table 1.

Perbedaan ukuran dan berat ikan gabus, toman, dan betutu dipengaruhi oleh pertumbuhan, jenis kelamin, makanan, dan lingkungan yang mendukung untuk pertumbuhan. Pertumbuhan merupakan perubahan yang terjadi pada ukuran, baik pada bobot maupun panjang. Panjang maksimal ikan gabus dapat mencapai 60$75 \mathrm{~cm}$, dan lebarnya dapat mencapai $12 \mathrm{~cm}$ (Requieron et al. 2012). Panjang total ikan toman berkisar $110-550 \mathrm{~mm}$ dan berat 18 $1.600 \mathrm{~g}$ (Siregar 2020). Ikan betutu yang terdapat pada Danau Toba memiliki panjang baku 14,9-28 cm (Aritonang et al. 2019).

Perbedaan proporsi bagian tubuh pada ikan disebabkan oleh ukuran, berat, dan jenis ikan. Ikan dengan ukuran bobot yang berbeda memiliki panjang tubuh serta proporsi tubuh yang berbeda pula karena panjang tubuh ikan berbanding lurus dengan bobot tubuh ikan gabus (Suwandi et al. 2014). Proporsi bagian tubuh ikan juga ikut bertambah mulai dari kepala hingga jeroan (Muthmainnah 2013).

\section{Kadar Protein Ekstrak Ikan}

Hasil uji lanjut statistika menunjukkan bahwa perbedaan jenis ikan memberikan pengaruh yang berbeda nyata terhadap kadar protein $(p<0,05)$ (Table 2). Chayati dan Andian (2008) melaporkan bahwa komposisi asam amino, penambahan garam, 
Table 1 Morphometrics of striped snakehead, giant snakehead, and marble goby

\begin{tabular}{lrrr}
\hline \multicolumn{1}{c}{ Parameter } & Striped Snakehead & Giant Snakehead & \multicolumn{1}{c}{ Marble Goby } \\
\hline Total length $(\mathrm{cm})$ & $24.10 \pm 1.15$ & $28.20 \pm 1.75$ & $24.1 \pm 1.01$ \\
Wide $(\mathrm{cm})$ & $3.47 \pm 0.15$ & $3.33 \pm 0.58$ & $5.17 \pm 0.29$ \\
Weight $(\mathrm{g})$ & $334 \pm 3.61$ & $346.67 \pm 2.08$ & $335.83 \pm 2.75$ \\
\hline
\end{tabular}

Table 2 Proteint content of striped snakehead, giant snakehead, and marble goby

\begin{tabular}{|c|c|c|c|}
\hline \multirow{2}{*}{ Treatment } & \multicolumn{3}{|c|}{ Protein content $(\mathrm{mg} / \mathrm{g})$} \\
\hline & Striped Snakehead & Giant Snakehead & Marble Goby \\
\hline Commercial extract & $1.52 \pm 0.17^{\mathrm{a}}$ & - & \\
\hline Fresh extract & $11.62 \pm 0.17^{\mathrm{a}}$ & $10.47 \pm 0.17^{\mathrm{b}}$ & $4.47 \pm 0.33^{c}$ \\
\hline Boiled extract & $6.28 \pm 0.57^{a}$ & $8.19 \pm 0.33^{b}$ & $2.95 \pm 0.17^{\mathrm{c}}$ \\
\hline Precipitated extract & $105.23 \pm 0.44^{\mathrm{a}}$ & $42.76 \pm 1.65^{\mathrm{b}}$ & $54.09 \pm 0.16^{c}$ \\
\hline
\end{tabular}

Note: different letter on the same row indicate a significant difference at $p<0.05$

waktu pemanasan, dan daya ikat air turut memengaruhi kadar protein. Jenis asam amino yang terikat dalam struktur protein akan memengaruhi sifat fisikokimia pada protein, yaitu stabilitas terhadap proses pemanasan. Asam amino lisina merupakan penyusun protein albumin terbesar pada ikan gabus mudah mengalami kerusakan karena panas yang menyebabkan menurunnya kadar protein. Penambahan garam juga berpengaruh terhadap kadar protein, karena garam dapat meningkatkan atau menurunkan kelarutan protein. Perubahan kelarutan protein dapat terjadi karena penambahan garam akan mempengaruhi ion dalam larutan. Kekuatan ion yang semakin meningkat mengakibatkan kelarutan protein semakin turun dan terendapkan.

Kadar protein tertinggi pada ekstrak ikan segar terdapat pada ikan gabus. Prasetyo et al. (2012) melaporkan bahwa ikan gabus merupakan jenis ikan air tawar dengan kandungan protein yang tinggi dibandingkan dengan ikan kakap, ikan mas, dan ikan bandeng. Kadar protein pada ekstrak ikan gabus, toman dan betutu mengalami penurunan setelah perebusan. Perbedaan kadar protein pada ekstrak ikan setelah direbus dapat disebabkan oleh jenis ikan, ukuran, umur, dan lingkungan.

Perebusan dapat menyebabkan kehilangan atau menurunnya zat gizi termasuk protein pada bahan pangan. Peristiwa tersebut dapat terjadi karena selama proses perebusan daging ikan terendam dalam air sehingga beberapa zat gizi larut air misalnya protein ikut terlarut dalam air rebusan yang mengakibatkan kadar protein menurun. Penurunan kadar protein juga terjadi akibat adanya denaturasi protein, karena jenis protein tertentu mudah terdenaturasi pada suhu diatas $55^{\circ} \mathrm{C}$.

Kadar protein kembali meningkat setelah presipitasi dengan amonium sulfat. Konsentrasi amonium sulfat terbaik pada ikan gabus dan betutu yaitu $80 \%$ sedangkan ikan toman $70 \%$. Pengendapan protein dapat terjadi oleh adanya penambahan pelarut organik atau senyawa lainnya. Penambahan garam dengan konsentrasi tinggi akan menyebabkan protein terendapkan. Efek salting out ini dapat terjadi karena adanya persaingan antara protein dan garam dalam interaksinya dengan molekul air. Air berinteraksi lebih kuat dengan garam dibandingkan dengan protein pada konsentrasi garam yang tinggi, menyebabkan protein memiliki kelarutan yang rendah sehingga kadar protein mengendap dan kadarnya kembali meningkat (Kusnandar 2010). Kandungan protein bersifat tidak stabil dan mempunyai sifat dapat berubah dengan berubahnya kondisi lingkungan (Georgiev et al. 2008).

\section{Profil Protein pada Ikan Gabus, Toman, dan Betutu}

Elektroforesis merupakan teknik untuk memisahkan molekul berdasarkan berat molekul karena adanya arus listrik yang 
diberikan (Magdeldin 2012). Sampel yang dianalisis dengan SDS-PAGE adalah sampel dari ekstrak ikan gabus komersial, ekstrak segar, hasil perebusan dan hasil pemurnian pengendapan amonium sulfat konsentrasi 70$90 \%$ berupa endapan dan filtratnya.

Hasil analisis elektroforegram (Figure 1) pada ekstrak ikan gabus komersial menunjukkan pita yang sangat tipis dan memiliki berat molekul sebesar $51,15 \mathrm{kDa}$. Hasil elektroforegram perlakuan pengendapan amonium sulfat pada konsentrasi tertentu menjadikan pita protein albumin lebih tebal. Pita yang tipis tersebut menunjukkan kandungan albumin yang jumlahnya sedikit. Magdeldin (2012) menyatakan bahwa semakin tipis pita protein, maka kandungan protein yang terkandung di dalamnya juga semakin sedikit.
Konsentrasi amonium sulfat $80 \%$ merupakan konsentrasi terbaik dalam mengendapkan protein albumin karena memiliki pita yang paling tebal jika dibandingkan pita albumin lainnya. Hasil tersebut sesuai dengan penelitian yang dilakukan oleh Fatoni (2007) yang menyebutkan bahwa konsentrasi amonium sulfat terbaik untuk mengendapkan protein albumin pada ikan gabus adalah konsentrasi $80 \%$. Konsentrasi amonium sulfat yang digunakan pada penelitian Firlianty et al. (2014) juga melaporkan konsentrasi amonium sulfat $80 \%$ untuk mengendapkan protein albumin dan memiliki berat molekul sebesar 53,92 $\mathrm{kDa}$.

Hasil elektroforegram pada Figure 1 menunjukkan bahwa ikan gabus memiliki beberapa jenis profil pita protein. Hasil

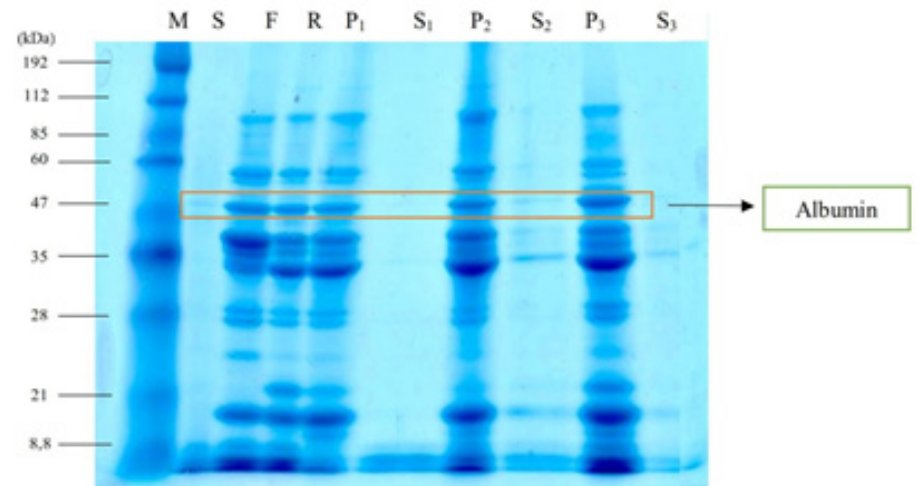

Figure 1 Electrophoregram SDS-PAGE of striped snakehead (M) Marker $192 \mathrm{kDa}$; (S) commercial extract ; (F) fresh extract; (R) boiled extract; (P1) pellets ammonium sulfate 70\%; (S1) supernatant ammonium sulfate 70\%; (P2) pellets ammonium sulfate $80 \%$; (S2) supernatant ammonium sulfate 80\%; (P3) pellets ammonium sulfate 90\%; (S3) supernatant ammonium sulfate $90 \%$

Table 3 Protein profile of striped snakehead

\begin{tabular}{|c|c|c|c|c|c|c|c|}
\hline \multirow[b]{2}{*}{ Band } & \multicolumn{6}{|c|}{ Molecule weight $(\mathrm{kDa})$} & \multirow[b]{2}{*}{ Protein Type } \\
\hline & $\begin{array}{c}\text { Commercial } \\
\text { extract }\end{array}$ & $\begin{array}{l}\text { Fresh } \\
\text { extract }\end{array}$ & $\begin{array}{l}\text { Boiled } \\
\text { extract }\end{array}$ & $\begin{array}{l}\text { Pellets } \\
70 \%\end{array}$ & $\begin{array}{c}\text { Pellets } \\
80 \%\end{array}$ & $\begin{array}{c}\text { Pellets } \\
90 \%\end{array}$ & \\
\hline 1 & - & 102.23 & 101.63 & 101.63 & 104.99 & 107.71 & $\beta$-galactosidase \\
\hline 2 & - & 59.26 & 59.12 & 59.26 & 60.53 & 60.53 & $\begin{array}{l}\text { Glutamate } \\
\text { dehydrogenase }\end{array}$ \\
\hline 3 & 51.15 & 51.77 & 51.97 & 51.77 & 52.59 & 52.55 & Albumin \\
\hline 4 & - & 34.38 & 34.48 & 33.97 & 34.28 & 34.69 & Carbonic anhydrase \\
\hline 5 & - & 27.69 & 27.52 & 27.46 & 28.06 & 28.00 & Myoglobin \\
\hline 6 & - & 20.26 & 19.74 & 22.54 & 23.37 & 25.52 & Lysozyme \\
\hline 7 & - & 9.17 & 8.47 & 8.8 & 9.17 & 9.36 & Aprotinin \\
\hline
\end{tabular}




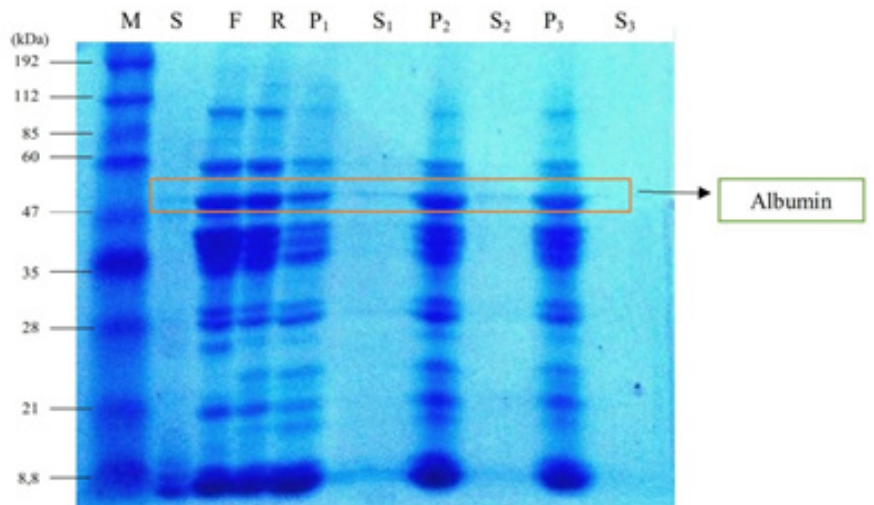

Figure 2 Electrophoregram SDS-PAGE of giant snakehead (M) Marker 192 kDa; (S) commercial extract ; (F) fresh extract; (R) boiled extract; (P1) pellets ammonium sulfate 70\%; (S1) supernatant ammonium sulfate 70\%; (P2) pellets ammonium sulfate 80\%; (S2) supernatant ammonium sulfate 80\%; (P3) pellets ammonium sulfate $90 \%$; (S3) supernatant ammonium sulfate $90 \%$

Table 4 Protein profile of giant snakehead

\begin{tabular}{|c|c|c|c|c|c|c|c|}
\hline \multirow[b]{2}{*}{ Band } & \multicolumn{6}{|c|}{ Molecule weight $(\mathrm{kDa})$} & \multirow[b]{2}{*}{ Protein Type } \\
\hline & $\begin{array}{c}\text { Commercial } \\
\text { extract }\end{array}$ & $\begin{array}{l}\text { Fresh } \\
\text { extract }\end{array}$ & $\begin{array}{l}\text { Boiled } \\
\text { extract }\end{array}$ & $\begin{array}{c}\text { Pellets } \\
70 \% \\
\end{array}$ & $\begin{array}{l}\text { Pellets } \\
80 \% \\
\end{array}$ & $\begin{array}{l}\text { Pellets } \\
90 \%\end{array}$ & \\
\hline 1 & - & 100.30 & 97.99 & 99.15 & 91.40 & 86.98 & $\beta$-galactosidase \\
\hline 2 & - & 60.95 & 58.91 & 59.45 & 59.27 & 58.18 & $\begin{array}{l}\text { Glutamate } \\
\text { dehydrogenase }\end{array}$ \\
\hline 3 & 51.99 & 52.54 & 52.17 & 51.44 & 52.36 & 51.62 & Albumin \\
\hline 4 & - & 39.48 & 39.31 & 39.31 & 38.80 & 37.66 & Carbonic anhydrase \\
\hline 5 & - & 28.78 & 28.70 & 28.62 & 28.38 & 28.00 & Myoglobin \\
\hline 6 & - & 20.45 & 20.45 & 20.34 & 19.87 & 18.48 & Lysozyme \\
\hline 7 & - & 9.63 & 9.63 & 9.30 & 9.36 & 9.37 & Aprotinin \\
\hline
\end{tabular}

pengukuran berat molekul pada profil ikan gabus dapat dilihat pada Table 3 .

Hasil elektroforegram ikan toman disajikan pada Figure 2, hasil yang diperoleh menunjukkan bahwa konsentrasi amonium sulfat $80 \%$ merupakan konsentrasi terbaik dalam mengendapkan protein albumin pada ikan toman karena memiliki pita yang paling tebal jika dibandingkan pita albumin lainnya. Estimasi berat molekul albumin pada ikan toman adalah $52 \mathrm{kDa}$. Penelitian yang dilakukan Firlianty et al. (2014) juga menggunakan konsentrasi amonium sulfat $80 \%$ untuk mengendapkan protein albumin pada ikan toman dan memiliki berat molekul sebesar 53,92 kDa.

Ikan betutu diduga mengandung albumin yang terlihat dari adanya pita protein albumin pada hasil elektroforegram SDS-PAGE (Figure 3). Estimasi bobot molekul protein albumin pada ikan betutu adalah $51 \mathrm{kDa}$. Estimasi berat molekul beberapa protein yang terdapat pada ikan betutu dapat dilihat pada Table 5 .

Hasil elektroforegram (Figure 3) menunjukkan bahwa konsentrasi amonium sulfat $80 \%$ merupakan konsentrasi terbaik dalam mengendapkan protein albumin pada ikan betutu karena memiliki pita yang paling tebal jika dibandingkan pita albumin lainnya. Hasil yang diperoleh pada Figure 1, 2, dan 3 menunjukkan bahwa terdapat protein albumin dengan bobot molekul berkisar antara 50-52 kDa. Hal tersebut menunjukkan bahwa pemurnian dengan pengendapan amonium sulfat berhasil memperoleh protein albumin walaupun belum murni karena masih terdapat beberapa jenis protein lainnya. Pemurnian lanjutan diperlukan untuk memperoleh protein albumin murni. 


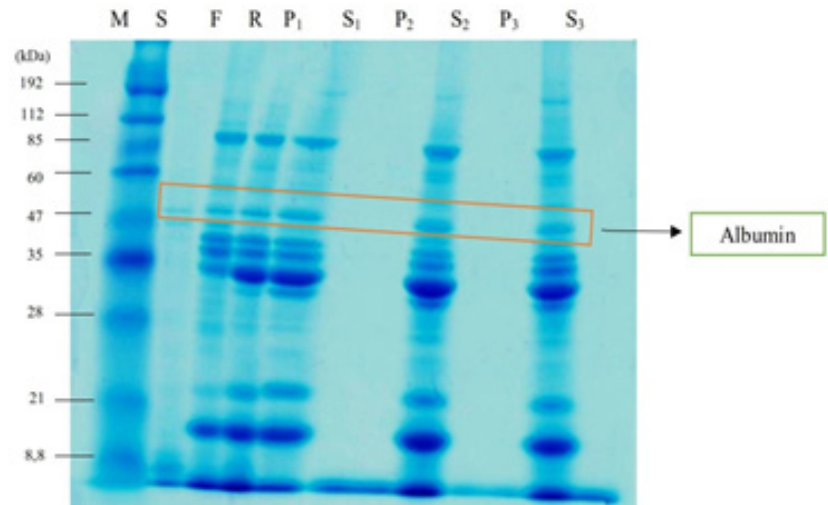

Figure 3 Electrophoregram SDS-PAGE of marble goby (M) Marker $192 \mathrm{kDa}$; (S) commercial extract ; (F) fresh extract; (R) boiled extract; (P1) pellets ammonium sulfate 70\%; (S1) supernatant ammonium sulfate 70\%; (P2) pellets ammonium sulfate $80 \%$; (S2) supernatant ammonium sulfate $80 \%$; (P3) pellets ammonium sulfate $90 \%$; (S3) supernatant ammonium sulfate $90 \%$

Table 5 Protein profile of marble goby

\begin{tabular}{|c|c|c|c|c|c|c|c|}
\hline \multirow[b]{2}{*}{ Band } & \multicolumn{6}{|c|}{ Molecule weight $(\mathrm{kDa})$} & \multirow[b]{2}{*}{ Protein Type } \\
\hline & $\begin{array}{c}\text { Commercial } \\
\text { extract }\end{array}$ & $\begin{array}{l}\text { Fresh } \\
\text { extract }\end{array}$ & $\begin{array}{l}\text { Boiled } \\
\text { extract }\end{array}$ & $\begin{array}{c}\text { Pellets } \\
70 \%\end{array}$ & $\begin{array}{l}\text { Pellets } \\
80 \%\end{array}$ & $\begin{array}{l}\text { Pellets } \\
90 \%\end{array}$ & \\
\hline 1 & - & 96.64 & 98.06 & 97.35 & 95.22 & 92.35 & $\beta$-galactosidase \\
\hline 2 & - & 58.15 & 57.78 & 57.78 & 57.78 & 57.22 & $\begin{array}{l}\text { Glutamate } \\
\text { dehydrogenase }\end{array}$ \\
\hline 3 & 51.30 & 51.49 & 51.49 & 51.30 & 51.82 & 50.70 & Albumin \\
\hline 4 & - & 36.67 & 36.49 & 36.49 & 36.15 & 36.32 & Carbonic anhydrase \\
\hline 5 & - & 18.78 & 18.21 & 17.98 & 17.38 & 17.01 & Myoglobin \\
\hline 6 & - & 8.94 & 8.80 & 8.42 & 8.29 & 7.92 & Aprotinin \\
\hline
\end{tabular}

Jenis protein lain selain albumin yang terdapat pada ikan gabus, toman, dan betutu antara lain adalah $\beta$-galaktosidase, glutamat dehidrogenase, karbonik anhidrase, lisozim, dan aprotinin. Enzim $\beta$-galaktosidase merupakan enzim yang dapat mengubah laktosa menjadi glukosa dan galaktosa. Enzim ini berfungsi untuk memudahkan pencernaan laktosa dalam usus (Drouault et al. 2002). Lisozim merupakan jenis protein globular yang salah satunya terdapat pada putih telur dan bersifat alergen (Saravanan et al. 2009). Jenis protein alergen yang terdapat pada ikan gabus, toman, dan betutu adalah protein lisozim.

\section{KESIMPULAN}

Karakteristik bahan baku yang dimiliki ikan gabus, toman, dan betutu berbeda satu sama lain. Kadar protein tertinggi pada ekstrak segar terdapat pada ikan gabus 11,62\%, ekstrak rebus terdapat pada ikan toman 8,19\%, dan setelah presipitasi dengan amonium sulfat terdapat pada ikan gabus $105,23 \%$. Jenis ikan air tawar lainnya selain ikan gabus yang memiliki protein albumin adalah ikan toman dan betutu.

\section{DAFTAR PUSTAKA}

Andreeva AM. 2010. Structure of fish serum albumins. Journal of Evolutionary Biohemistry and Physiology. 46(2): 135144.

Alviodinasyari R, Pribadi ES, Soejoedono RD. 2019. Kadar protein terlarut dalam albumin ikan gabus (Channa striata dan Channa micropeltes) asal Bogor. Jurnal Veteriner. 20(3): 436-444.

Aritonang SJ, Efizon D, Windarti. 2019. Pola pertumbuhan ikan betutu (Oxyeleotris marmorata) di Perairan Danau Toba Kecamatan Haranggaol Kabupaten 
Simalungun Provinsi Sumatera Utara. Jurnal Online Mahasiswa. 6(2): 1-8.

Asikin AN, Kusmaningrum I. 2018. Karakteristik ekstrak protein ikan gabus berdasarkan ukuran berat ikan asal DAS Mahakam Kalimantan Timur. Jurnal Pengolahan Hasil Perikanan Indonesia. 21(1): 137-142.

Baie SH, Sheikh KA. 2000. The wound healing properties of Channa striatus -cetrimide cream- tensile strength measurement. Journal Ethnopharmacol. 71(1): 93-100.

Drouault S, Anba J, Corthier G. 2002. Streptococcus thermophillus is able to produce a $\beta$-galactosidase active during its transit in the digestive tract of germfree mice. Journal American Society for Microbiology. 68(2): 116-123.

Fatoni R. 2007. Pengaruh konsentrasi ammonium sulfat pada presipitasi albumin ikan gabus (Ophiocephalus striatus). [tesis]. Malang (ID): Universitas Brawijaya.

Firlianty, Suprayitno E, Hardoko, Nursyam H. 2014. Protein profile and amino acid profile of vacuum drying and freezedrying of family channidae from central Kalimantan, Indonesia. International Journal Bioscience. 5(8): 75-83.

Firlianty, Rario, Naibaho EB, Elita. 2019. Karakteristik gel HPMC ekstrak ikan toman (Channa micropeltes). Jurnal Agribisnis Perikanan. 12(1): 8-12.

Fitriyani E, Deviarni IM. 2018. Pengaruh suhu dan waktu ekstraksi ikan toman (Channa micropeltes) menjadi serbuk albumin. Jurnal Galung Tropika. 7(2): 102-114.

Fitriyani E, Nuraenah N, Deviarni IM. 2020. Perbandingan komposisi kimia, asam lemak, asam amino ikan toman (Channa micropeltes) dan ikan gabus (Channa striata) dari Perairan Kalimantan Barat. Marine, Environment, and Fisheries. 1(2): 71-82.

Georgiev L, Penchev G, Dimitrov D, Pavlov A. 2008. Structural changes in common carp (Cyprinus carpio) fish meat during freezing. Bulgarian Journal of Veterinary Medicine. 2(2): 131-136.

Jamaluddin JAF, Pau TM, Azizah MNS. 2011. Genetic structure of the snakehead murrel, Channa striata (Channidae) based on cytochrome $\mathrm{c}$ oxidase subunit I gene: Influence of historical and geomorphological factors. Genetic and Molecular Biology. 34(1): 152-160.

Kusnandar F. 2010. Kimia Pangan Komponen Makro. Jakarta (ID): Dian Rakyat.

Laemmli UK. 1970. Cleavage of structural protein during the assembly of the heat of bacteriophage T4. Nature. 227(10): 680685.

Magdeldin S. 2012. Gel ElectrophoresisPrinciples and Basics. pg 15-32. Kroasia (HR): Intech Publishing.

Muhammad A, Tawali AB, Abdullah N, Mahendratta M. 2014. Extraction of albumin snakehead fish (Channa striatus) in producing the fish protein concentrate (FPC). International Journal of Scientific \& Technology Research. 3(4): 85-88.

Muthmainnah D. 2013. Hubungan panjang berat dan faktor kondisi ikan gabus (Channa striata Bloch, 1973) yang dibesarkan di rawa Lebak, Provinsi Sumatera Selatan. Jurnal Depik. 2(3): 184190.

Nugroho M. 2012. Pengaruh suhu dan lama ekstraksi secara pengukusan terhadap rendemen dan kadar albumin ikan gabus (Ophiocephalus striatus). Jurnal Teknologi Pangan. 3(1): 64-75.

Nugroho M. 2012. Isolasi albumin dan karakteristik berat molekul hasil ekstraksi secara pengukusan ikan gabus (Ophiocephalus striatus). Jurnal Teknologi Pangan. 4(1): 1-18.

Prasetyo MN, Sari N, Sri CB. 2012. Pembuatan kecap dari ikan gabus secara hidrolisis enzimatis menggunakan sari nanas. Jurnal Teknologi Industri. 1(1): 329-337.

Requieron EA, Anthony MJT, Demayo CG. 2012. Applications of relative warp analysis in describing of scale shape morphology between sexs of the snakehead fish Channa striata. International Journal of Biological, Ecological, and Environmental Sciences. 1(6): 2277-4394.

Saravanan R, Shanmugam A, Ashok, Kumar DS, Anand K, Suman A, Devadoss FR. 2009. Studies on isolation and partial purification of lisozyme from egg white 
of the Lovebird (Agapornies sp.). African Journal of Biotechnology. 8(1): 107-109.

Sari DK, Rosidi A, Rahmawati H. 2017. Profil albumin dan betakaroten formula bayi instan. Jurnal Pengolahan Hasil Perikanan Indonesia. 20(3): 602-608.

Siregar EY, Putra RM, Eddiwan. 2020. Morfometrik, meristik dan pola pertumbuhan ikan toman (Channa micropeltes Cuvier, 1831) di waduk
PLTA Koto Panjang Desa Pulau Gadang Kecamatan XII Koto Kampar Kabupaten Kampar Provinsi Riau. Jurnal Online Mahasiswa. 7(1): 1-12.

Suwandi R, Nurjanah, Winem M. 2014. Proporsi bagian tubuh dan kadar proksimat ikan gabus pada berbagai ukuran. Jurnal Pengolahan Hasil Perikanan Indonesia. 17(1): 22-28. 